\title{
Towards understanding migration within God's redemptive plan for humankind: A case of Matthew's genealogy in connection with the Old Testament
}

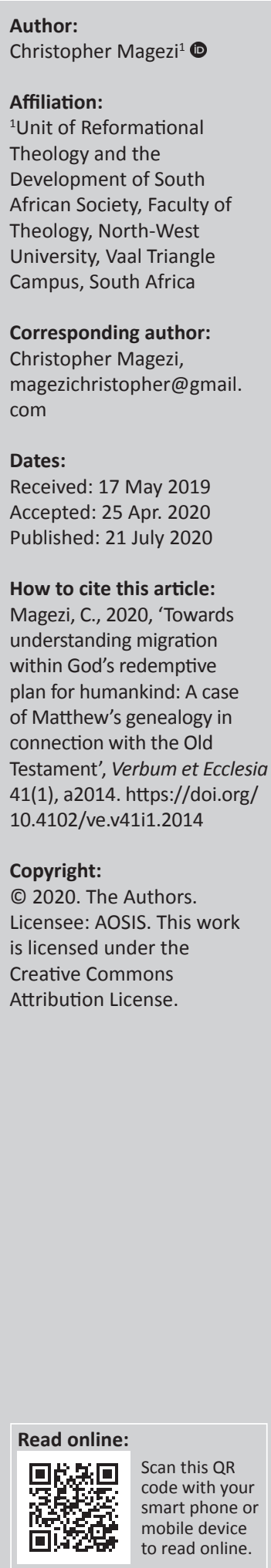

This article responds to the emerging need for theology to be more engaged in the issue of migration and to develop a thorough biblical-theological foundation for a migration theology that challenges the Church to effectively respond to the challenges faced by migrants. This is accomplished by utilising Matthew's genealogy in a quest to explore God's use of migration to accomplish his redemptive purposes and plans for humankind. Although Matthew's genealogy cites many patriarchs of Israel, such as Abraham, Isaac and Jacob - all of whom are involved in various migrations that God uses to advance his redemptive plans and purposes for humankind - the focus of this article is to underscore that the salvation and inclusion of some women from Gentile ethnic groups, specifically Tamar, Rahab and Ruth, in Matthew's genealogy emphasises the importance of migration in redemptive history. Through this insight, the article challenges humanity to respond positively to migrants' challenges, as well as implores theology to engage more in migration issues/debates. On the one hand, God brings migrants to people's doorsteps for purposes that are unknown to them, i.e. the Bible envisages a situation in which, when God wants non-believers to know him, he migrates them to where his people are. On the other hand, God also advances his kingdom by migrating his people (Christians) to faraway places so that they may be in contact with non-believers.

Intradisciplinary and/or interdisciplinary implications: This is an interdisciplinary article that brings both the Old and New Testaments into conversation with each other regarding the subject of migration in redemptive history. The contribution of the article lies in recovering the importance of migration in redemptive history.

Keywords: church; migration; Matthew; lineage; genealogy; Tamar; Rahab; Ruth; migration in redemptive history; church response to migrant challenges.

\section{Introduction}

With the ongoing issue of migration, it is becoming ever more crucial to develop a thorough biblical-theological foundation for migration theology that challenges the Church to effectively respond to both the challenges faced by migrants, as well as articulate a theology of migration that challenges theology to claim its space in the migration discourse. In this regard, the paper ventures on a quest of God's use of migration to accomplish his redemptive purposes and plans for humankind by making use of Matthew's genealogy as one of the biblical-theological foundations for a migration theology that responds to the proposed needs. The ensuing section will provide a background to the study, followed by problem identification.

\section{Study background: A terrain sketch and problem identification}

Migration has both local and international dimensions (Skeldon 2013:2). On the one hand, the local aspect of migration refers to the movement of people from one place to another within their country of origin, e.g. people moving from rural to urban areas in their own countries of origin in order to seek employment (Skeldon 2013:2). On the other hand, the international concept of migration refers to the movement of people across borders. Skeldon (2013:2) defines both of these local/internal and international dimensions of migration as a 'move from an origin to a destination, or from a place of birth to another destination across international borders'. However, when focusing on the issue of international migration, Groody (2009:640) affirms the issue of the increment of the number of international migrants as 'complex and far-reaching' because the 
rapidly swelling numbers of international migrants pose challenges for both hosting nations and the migrants themselves.

On the one hand, migrants face many challenges, such as the following. Firstly, migrants experience discrimination in various forms, i.e. some hosting nations do not recognise foreign qualifications, which results in the migrants accepting low-paying jobs in order to survive in their new homelands (Bose 2014:23; Datta et al. 2006:8; Kul 2011). Secondly, migrants encounter burdensome migration regulations that are imposed by the hosting nations as a means of discouraging migrants from entering into these countries. For example, hosting nations tighten their borders and impose onerous visa requirements (Chelius 2014:32-33; Gilmore 2016; Rajendra 2014:305; Ridsdel 2014:27-28; Sazonov 2015). Thirdly, migrants encounter challenges such as unemployment, language problems, lack of access to basic services like hospital/clinic services and xenophobia (Magezi 2018:219-235). Xenophobia is described by Harris (2002:169) as 'dislike, hatred or fear of foreigners'. In saying this, we are conscious that xenophobia is not just an attitude, but it constitutes action, since many of these attitudes manifest themselves in practical ways (Gopal 2013:129; Harris 2002:169). On the other hand, migranthosting countries face the following challenges: bearing the cost of resettling and integrating the migrants (Boundless 2015; Nie 2015; Thomsen 2016:17); the increment in the rates of unemployment (Rivera-Pagán 2012:575); the dilution of their native cultures (Corhen \& Sirkeci 2011:1; Tan 2012:47); threats from the refugees' opponents (Pakoz 2016); and the suspicion that migrants, particularly refugees, are inextricably linked with terrorism (Louw 2016:5; Plucinska 2015).

However, Groody (2009:640), Heimburger (2015:338) and Magezi (2017:2) lament that although the existential challenges of both migrants and hosting nations are real and the international community cannot afford to ignore them, theology has not really been participating in shaping the discourse surrounding migration (Groody 2009:640; Heimburger 2015:338; Jackson \& Passarelli 2016:46). In other words, these scholars/theologians argue that theology has not been at the centre of the debate of migration issues. Groody (2009:639-641), who provides a comprehensive treaty on migration from a theological point of view, clearly maintains that 'among theologians the topic of migration is undocumented' (Groody 2009:640). What we usually see in academic literature is the pastoral care of immigrants, which has been largely published by the 'Vatican and various episcopal conferences' (Groody 2009:639). In other words, whilst various academic disciplines, such as 'economics, politics, geography, demography, sociology, psychology, law, history, anthropology, and environmental studies are foremost among the disciplines that shape the emerging field of migration studies and migration theory', Groody (2009:640) perceives that the discipline of theology has not been shaping the field of migration, as if it does not have anything to offer on the issue. Theology as an academic discipline (Groody 2009):

\begin{abstract}
... is almost never mentioned in major works or at centres of migration studies. Some research has been done on migration and religion from a sociological perspective, but there is virtually nothing on the topic from a theological perspective. Theology seems to enter the academic territory from the outside, as if it were a 'disciplinary refugee' with no official recognition in the overall discourse about migration. (p. 640)
\end{abstract}

Likewise, Heimburger (2015:338) presents migration as an emerging issue for the international/global community that has received little attention in theological discourses. After underscoring the aspect of Christians as pilgrims on the way, as well as the picture of the eternal-transcendent-God who dwells amongst us, as the basis for the involvement of theology in the migration issue, Heimburger (2015) observes that:

[d]espite the fact that migration offers fertile ground for theological reflection, it has received little extended theological attention. Apart from some interest in the subject by biblical scholars, no more than a handful of academic monographs have dealt with the subject in recent decades. (p. 338)

As a result of this indictment, it is not surprising that in Mapping migration, mapping churches' responses in Europe, Jackson and Passarelli (2016:46) argue that theological institutions are urged to develop programmes in their undergraduate curricula 'which will incorporate the studies of migration and migrants' as components of study. The introduction of migration and migrant studies at undergraduate level would be 'a necessary contribution to the important and vital task of developing a theological account of the phenomenon of migration' (Jackson \& Passarelli 2016:46). This abovementioned discussion indicates that very little migration-related research has been done from a theological perspective. Given this, we argue together with Groody (2009) that:

[t] he current climate points to the need to move the migration debate to an even broader intellectual terrain, one in which theology not only has something to learn but something to offer. (p. 641)

However, one can argue that one of the reasons migration issues are at the periphery of theological discussion is a lack of a biblical-theological foundation for migration theology. In Magezi's (2018:305-321) view, this lack has resulted in inadequate responses to migrants' challenges in current South African churches. In the wider context of his research, Magezi (2018) conducted a qualitative research study that involved interviewing various church leaders in the Gauteng province. In this study, Magezi (2018) establishes that the theological rationales that drive the South African churches' structured and unstructured migrant ministries are limited in many and different ways. Firstly, some current South African church leaders have used and justified theological rationales for their structured and unstructured migrant ministries. Such rationales are derived from the use of ill-suited biblical texts (Magezi 2018:314-316). Secondly, because of their theological rationales, some current South African churches 
do not have structured migrant ministries (Magezi 2018: 316-320). The abovementioned discussion brings to the fore the reality that theological reflection on migration still has a long way to go to reach maturity (Campese 2012:30). Campese (2012:5-6) views migration as a serious emerging issue in theological discourse by asserting that 'today's rapidly changing social and political realities challenge Christian churches and theology to deal seriously and urgently with the phenomenon of human mobility'. Indeed, this clearly indicates a lacuna for well-articulated theologies of migration that challenge the churches to respond to migrants' challenges in effective ways, as well as for theology to claim its space in the discourses surrounding migration.

Given this emerging need for theology to engage more actively in the issue of migration, and for a thorough biblicaltheological foundation for migration theology that challenges churches to respond emphatically to migrants' challenges, this article is a study, utilising Matthew's genealogy, of God's use of migration to accomplish his redemptive purposes and plans for humankind. Although Matthew's genealogy alludes to many patriarchs of Israel such as Abraham (Gn 12:1-3, 10-20), ${ }^{1}$ Isaac (Gn 26) ${ }^{2}$ and Jacob (Gn 46) ${ }^{3}$ who were involved in various migrations that God utilises to advance his redemption plans for humankind, this paper seeks to underscore the fact that the salvation and inclusion of women of Gentile ethnic origin, specifically Tamar, Rahab and Ruth, in Jesus' genealogy emphasise the importance of migration in redemptive history. In order to accomplish the aforesaid, Section 3 will examine the various migrations in the Old Testament (OT) that are interlinked with the salvation and inclusion of these aforementioned Gentile women in Matthew's genealogy. This is done to underscore the fact that these women were saved and included in Jesus' genealogy because they played crucial roles, together with many others, in ways that illustrate the role and place of migration in God's redemptive plan.

Following this, Section 4 will present a dialogue with the various views regarding the inclusion of women of Gentile ethnic origin (i.e. Tamar, Rahab and Ruth) in Matthew's genealogy, a subject that has been studied, discussed and confirmed as valid by a considerable number of scholars / theologians (cf. Botha 2006; Garland 1979; Heffern 1912; Heil 1991:538-545; Hill 1972; Hutchison 2001; Lee 2007; Morris 1992; Nolan 1979; Nowell 2008). This buttresses the argument

\section{In his grace and love to bring salvation to all nations, God calls Abraham to leave his pagan nation, and migrate to the promised land of Canaan that God is going to give Abraham as a treasured possession (Gn 21:1-3). God is involved in the migration of Abraham in order to bring to fulfilment his first gospel promise of Genesis 3:15. However, in the unfolding of God's redemptive plans and purposes for humankind However, in the unfolding of God's redemptive plans and purposes for humankind, Abraham is forced to migrate to Egypt when famine strikes in the land of Canaan ( $\mathrm{Gn}$ 12:10-20). This depicts God's will for Abraham to migrate to Egypt in order to fulfil
his redemptive promises to Adam and his descendants (Gn 3:15), which God committed to establish through Abraham and his descendants in the context of his} call of Abraham to migrate to the Promised Land (Gn 12:1-3).

2.Genesis 26 reveals that, when famine strikes in the land of Isaac's abode, he migrates to Gerar (Arnold 2009:236-241; Motyer 1986:108). The Lord appears to Isaac, and warns him not to migrate further to Egypt, but to stay in Gerar (Motye Isaac, and warns him not to migrate further to Egypt, but to stay in Gerar (Motye 1986:108-109). It is at Gerar where God renews his Abrahamic covenant promise with Isaac (Gn 26:2-6). It seems God allows Isaac's migration to Gerar so that he can save him from famine and unleash his (God's) redemptive plans for humanity

3.Genesis 46 reveals the migration of Jacob and his whole household to Egypt because of famine in the land of Canaan. that Tamar, Rahab and Ruth are included in Jesus' lineage in order to demonstrate the crucial roles they play in the unfolding of God's redemptive plan for humankind. This plan always includes migration as part of the redemptive history, thus demonstrating the redemptive importance of migration issues. Once this importance has been established, the paper will conclude by challenging churches to adopt effective responses to migrants' challenges, and advocating for theology to claim its rightful place in discourses pertaining to migration, as migration has always been an instrument used by God to advance his redemptive purposes for humanity. In God's scheme, migration is not an accident and, for this reason, the Church ought not to view it as such.

\section{How the salvation and inclusion of Tamar, Rahab and Ruth in the advancement of God's salvific purposes for humankind illustrate the importance of migration in redemptive history}

\section{Judah's migration to Kezib in the Old Testament results in Tamar's inclusion in the advancement of God's salvific purposes}

The narrative of Judah's migration to Kezib (Gn 38:1-30) is worth discussing because of its linkage to the unfolding of God's redemptive purposes and plans. Genesis 37 stipulates that, owing to Jacob's sons' jealousy of their younger brother, Joseph, the older brothers end up selling him (Joseph) to the Midianites, who then take Joseph with them to Egypt. After this event, Judah (one of Joseph's brothers) leaves his brothers and goes to stay with a man of Adullam, named Hirah (Gn 38:1; Motyer 1986:163).

In that foreign land, Judah marries a Canaanite woman (Shua) who bears him three sons, namely Er, Onan and Shelah (Gn 38:3-11; Arnold 2009:325-329). Judah's first son, Er, marries Tamar (a Canaanite woman). Because Er is wicked, God kills him (Gn 38:7; Motyer 1986:163). Onan is given his brother's wife so that he can bear offspring for his late brother, but since he knows that the offspring in this marriage will not be his, whenever he lies with his brother's wife he spills his semen on the ground so as not to produce offspring for his brother (Gn 38:9). Because of this wickedness, Onan is killed by God.

However, when Onan dies, Judah deceives his daughter-inlaw by promising that when Shelah becomes of age, he will marry her, yet, in principle, Judah is lying because he is afraid that Shelah will die just like his brothers (Gn 38:11; Arnold 2009:327). Having noticed that deception, Tamar disguises herself as a prostitute and entraps Judah to sleep with her. As a result, Tamar conceives twins, Perez and Zerah (Gn 38:1230; Arnold 2009:327; Motyer 1986:165). From a redemptive historical approach, Judah's migration from his brothers is important because, through this migration, God uses Judah's faults to bring Perez, whom Jesus Christ is a true descendant 
of, into the world. In the New Testament (NT), Judah, Tamar and Perez are mentioned in the genealogy of Jesus (Mt 1) as significant people whom God utilises in bringing his redemptive purposes and plans to fulfilment (Rosenblum 2002). In his article, titled Tamar times three, Rosenblum (2002:127) argues that without the Tamar of Genesis 38 biblical history might have come to a grinding halt. Referring to Tamar, Rosenblum (2002) asserts that:

[s] he is a heroine because from her union with Judah comes her son Perez, and from the line of Perez comes King David (I Chron 2:4-16; Ruth 4:17-21) and the founding of the Kingdom of Israel that for a brief while was to encompass all 12 tribes. It is David who establishes Jerusalem as the capital of the new nation and it is David's son Solomon who builds the first Temple within Jerusalem's walls. The importance of Tamar is thereby established without question. (p. 129)

This clearly indicates that God is involved in the migration of Judah, which he (God) utilises to accomplish his redemptive purposes and plans for humankind. This implies that Tamar, together with many others, comes to be in Jesus' lineage in order to play a crucial role in illustrating the use of migration for redemptive purposes. In other words, it is within the context of a migration narrative that Judah is involved in a sexual sin with Tamar (a Gentile woman), who then saves the line of Judah, from which the royal line would arise. However, at this juncture, one can question the fostering of Jesus' genealogy from a migration story that is embedded in a sexual sin. In responding to this question, one is persuaded to concur with Arnold (2009), who argues that:

God's purpose is not thwarted by human sin, but rather advanced by it through his good grace. The hand of God is seen, not only in clearly miraculous interventions and revelations, but also in the working out of divine purposes through human agency, frail and broken as it is. (p. 361)

\section{The Israelites' migration to Canaan results in the salvation and inclusion of Rahab in the advancement of God's redemptive purposes for humankind}

It is important to note that, in the redemption and migration of the Israelites from Egyptian bondage to the promised land of Canaan, God migrates them to accomplish his redemptive purposes and plans for humankind. God migrates Israel to Canaan so that there would be remnant Gentile people amongst the Israelites that God, in his providence, would graciously save and, over time, even incorporate into Israel (Ford 2017:161-184; Grisanti 1998:40; Magezi 2018:52-55). In his article titled The challenge of the Canaanites, Ford (2017:161184) looks at the story of the conquest of Canaan by the Israelites (under the leadership of Joshua), along the overarching story of God's salvation to all people through Israel, as Genesis 12:3 attests to. That is the goal of the salvation of all nations that God promises to accomplish through Abraham, and his descendants should always be one of the theological features that help humankind to understand the challenges associated with the understanding of the conquest of Canaan (Ford 2017). In his article titled
Israel's mission to the nations in Isaiah 40-55: An update, Grisanti (1998) underscores the salvation of the Gentile nations or people during and after the conquest of Canaan by affirming that:

[b]y means of the Law, Yahweh clearly demonstrated that Israel's relationship with Him demanded a moral and ritual distinctiveness (Lv 11:44-45, 19:2). Prior to their entrance into Canaan, Yahweh instructed His chosen people to exterminate all the inhabitants and to avoid every pagan custom in order to maintain their uniqueness. As the nation of Israel developed, certain Gentiles enjoyed divine redemptive benefits only by virtue of their access to Israel. (p. 40)

In light of the above, it should be borne in mind that Rahab is from a Gentile ethnic group, the Canaanites. Rahab's story in Joshua 2:1-21 (cf. 6:17, 22, 23, 25) illustrates that God, in his providence, migrates the Israelites to Canaan so as to graciously save a remnant of Gentile people, whom he later uses to advance his redemptive purposes and plans for humankind.

It is common knowledge that when God migrates the Israelites from Egyptian bondage and leads them to take possession of the Promised Land (Canaan), he commands them to completely exterminate the inhabitants of the land of Canaan, including men, women and children (Dt 7:2, 20:17) (cf. Ford 2017; Grisanti 1998:40). This indicates that the battle God commands the Israelites to wage is not simply a religious war. Instead, it is a theocratic war. The Israelites are a people and nation ruled by God, so the order for them to exterminate the Canaanites is a direct command from God (Geisler 1977:99-100). However, from a close reading of Leviticus 18:24-25, the reason for the total destruction of the Canaanites was sin (Ford 2017:165). This is substantiated by texts such as Deuteronomy 9:5 and 18:9, in which God speaks of driving out the Canaanites from the land of Canaan because of their wickedness and detestable practices (Ford 2017:165). So, Israel, as a theocratic nation, should not be like the Canaanites (Dt 18:9), as Israel's survival lies in obedience and loyalty to God's law (Dt 28-30). However, looking at God's command for the Israelites to destroy all the inhabitants of Canaan because of their sins and wickedness (Dt 20:7), it can be surmised that, from the notion that Abraham and his descendants are God's instruments of salvation to all nations or people, those Canaanites and other nations who give up their wicked and detestable ways, including pagan gods, and acknowledge Israel's God as the only true God to be worshipped, are not supposed to be destroyed because they have pledged their faith to the God of Israel (Magezi 2018:52-55).

However, the Canaanites that have not given their lives to the God of Israel are a threat to Israel's faith (Ford 2017:166). That is, although the concept of the judgement of the Canaanites for their sins is evocative in the previous discussion, it is also apparent that they are portrayed as a danger to Israel's faith and the nature of this danger is not military but religious (Ford 2017). Indeed, as Ford (2017) posits, the Canaanites are not a military threat to Israel because, if God is with Israel, it 
is automatic that the Canaanites will be defeated. The religious danger is that the Israelites are prone to be tempted to follow the pagan gods of the Canaanites and, therefore, compromise their relationship with God. This arises from the explicit warnings about the Canaanites that God gives to the people of Israel before they possess the land of Canaan (cf. Dt 1:26-31, 2:24-25, 3:21, 7:17-24, 9:1-13 \& 20:1; Ford 2017:167). Together with Ford (2017), it can be emphatically argued that the reasons for such warnings are because:

[s]uch behaviour is abhorrent to YHWH (Deut. 12:31; cf. 18:12; 20:18); it is a snare for Israel (Exod. 23:33, 34:12; Deut. 7:16), and it will lead to their destruction (Deut. 6:14-15, 7:4, 8:19). This extreme danger is the context in which YHWH commands the destruction of the Canaanites. Israel must do whatever it takes to avoid idolatry. The specific outworking of this destruction focuses on two main areas: a prohibition against intermarriage, and the command to destroy their religious paraphernalia. (p. 167)

Having established that, this paper maintains that the Canaanites who acknowledge the God of Israel as the only true God to be worshipped are not to be destroyed because they have paid their allegiance to the God of Israel and, therefore, are not a danger to Israel's faith in God (Magezi 2018:53-54). Given this, God's command for the Israelites to exterminate the Canaanites and other nations, therefore, should also be read in view of the redemption that God had aimed to execute through Abraham (Gn 12:3), Isaac (Gn 26:3-5), Jacob (Gn 32:9-12, 35:12) and the nation of Israel (Is 40-55) (cf. Ford 2017:162; Grisanti 1998:40; Magezi 2018:5255). The story of Rahab indicates that, from the universal redemption that God sets out to accomplish through the Israelites, the latter are not commanded to exterminate all, but only those that would have resisted living under them and serving the only true God of Israel (Magezi 2018:55). For instance, Rahab, a prostitute in Jericho, hears about the God of Israel and acknowledges him as one who is worth risking her life for. She hides the Israelite spies who come to spy on the city of Jericho. The spies, who are sent by Joshua to Jericho (Jos 2:1-2), come to lodge in the house of Rahab for the night. The news of the spies reaches the king of Jericho (Jos 2:3), who demands that Rahab brings them out of her house, but Rahab lies that they had left, whilst she is actually hiding them on the roof of her house (Jos 2:4-6). Rahab sends the soldiers of Jericho in one direction, before releasing the spies to go in another direction, to proceed with their mission.

In Joshua 2:8-11, it is clear that Rahab gives up her pagan gods and acknowledges the God of Israel as the only true God, based on his (the God of Israel's) works that she has heard of. Also, Rahab pleads with the spies to spare her and everyone in her household (Jos 2:12-14). The spies swear an oath to spare Rahab and members of her household if she (Rahab) does not disclose their mission to the authorities or anyone in Jericho. Later, a fierce battle is fought between Israel and Jericho, and the city of Jericho is destroyed. In line with the oath that the spies had made to Rahab, Joshua gives orders for her and all the members of her household to be spared (Jos 6). Hence, Rahab and her household members are rescued, and they subsequently dwell amongst the Israelite community. Given this, it can be postulated that the migration of the Israelites from Egyptian bondage to Canaan is not outside God's plan and control, since, in his providence, God uses that migration to save some remnants of the Gentile people of Canaan, such as Rahab and members of her family (Ford 2017:162). As Ford (2017) argues:

[t]he inherent difficulty of the divinely commanded violence is exacerbated by the fact that this is not in an obscure part of the Bible, but rather linked to the promises and YHWH's plan of salvation. (p. 162)

In other words, although God commands the Israelites to exterminate the foreign nations they find, as a means of judgement for their sins, and as part of the fulfilment of God's covenant promise to give the land of Canaan to Abraham and his descendants, it is apparent that a redemptive historical perspective sees God's grace, even in the form of judgement. That is, as God judges the Canaanites for their sins, he is gracious in judgement, as he saves some Gentile ethnic people, in this case Rahab and her household. Having established this, the invasion of Canaan by the Israelites under divine command can be viewed as a means of fulfilling one of the particular aspects of the Abrahamic promises, namely the promise of the land that is partially fulfilled at this point of redemptive history (cf. Gn 12:3, 15, $17: 1-16)$.

It can also be advanced that the promise of the land had already been partially fulfilled; this argument can be supported by the fact that, prior to the exodus, Jacob's sons had managed to return to Canaan to bury their father in the promised land (Gn 49: 29-33). In addition, Joseph reveals that the descendants of Abraham own a piece of land in Canaan, in terms of what his father, Jacob, had said to him just before he died. Joseph and his brothers bury their father in the land of Canaan, as they had been instructed by Jacob himself (Gn 50:1-21). This point serves to highlight that the promises were not yet fully realised, but that God had already started to fulfil them. This is important because, even after the conquest of the land of Canaan, the book of Joshua gives evidence that not all of the land was attained by the time Joshua bids Israel farewell (Jos 22). In fact, the whole OT, even at the climax of David's reign, manifests a looking forward to complete rest or fulfilment of the promises (Ps 22:110). God had started, but had not yet finished, working towards the promises he made to Abraham (Gn 12:3, 15, 17:1-16) and then repeats to both Isaac (Gn 26:3-5) and Jacob (Gn 32:9-12, 35:12). These promises are later cited in Exodus 2:24 and 6:4-5 as the basis for God's deliverance of the Israelites from Egyptian bondage.

It can also be understood that the conquest of Canaan is God's judgement of the foreign nations for their sins. The Canaanite nations do not acknowledge the God of Israel as the only true God, the Creator, who owns the whole land. 
Instead, they worship their pagan gods. Furthermore, their lifestyle does not conform to God's standards; hence, the invasion is a form of God's judgement of pagan nations for their sins (wicked, unjust, and detestable practices). Inter alia, the judgement suffered by the Canaanites consists of land dispossession (Japhet 2006:113; cf. Athas 2016:9). However, in all these interpretations, God's command for the real extermination of the Canaanites from their land can also be perceived, yet it is not just a mere extinction of the pagan nations, because God is doing something in his larger redemptive purposes for humankind (cf. Ford 2017:162; Grisanti 1998:40; Magezi 2018:53-54). In accordance with God's redemptive purposes and plans for the world, the Israelites both welcome and incorporate aliens into their community, as long as the latter give up their pagan gods and acknowledge the God of Israel as the only true and sovereign God, who is giving the land of Canaan to the Israelites.

The predominant argument is that God uses migration to advance his kingdom and, accordingly, migrates the Israelites to advance his redemptive purposes and plans for humankind, as perceived in Rahab's redemption and inclusion into the Israelite family and community. Rahab's story reaches its climax as, later in the Scripture, she marries Salmon, and then gives birth to Boaz (Mt 1:5). Boaz marries a Moabite woman, Ruth, who gives birth to Obed, the father of Jesse, who then sires David, from whose line Jesus, the Saviour of the world, descends (Mt 1:1-16).

\section{The migration of Elimelech, Naomi and his family to Moab results in the salvation and inclusion of Ruth in the advancement of God's salvific purposes for humankind}

The background of Ruth's narrative is that, in the days when the judges ruled in Israel, famine broke out in the land of Judah (Rt 1:1-2) and Elimelech, a man from Bethlehem, migrates to Moab with his wife Naomi and their two sons, Mahlon and Chilion, and settles there (Rt 1:1-2). Later, Elimelech dies and leaves Naomi with her two sons, who both marry Moabite women, namely Orpah and Ruth (Rt 1:3-4). Naomi and her two sons continue to live in Moab for another 10 years after the death of Elimelech (Rt 1:4b). However, the sons also later die (Rt 1:5). After the death of her sons, Naomi decides to leave Moab for Judah, after hearing the good news that the covenant God of Israel had visited his people of Judah and given them food (Rt 1:6-7; Ulrich 2007:53). Given the news of God's providence to the people of Judah, Naomi sets out to return to Judah, but advises her daughters-in-law to return to their fathers' households and remarry, as this would be safer for them than to sojourn with her to Judah, where they would be strangers (Rt 1:8-18). Initially, Orpah and Ruth leave with Naomi, but along the way, Naomi tells them to turn back, which Orpah does $($ Rt $1: 7,14)$. Ruth vows to continue with Naomi to Judah (Rt 1:16-19). As a result of Ruth's insistence, Naomi allows her to accompany her to Judah at the beginning of the barley harvest (Rt 1:19-22). However, even today, Ruth's decision raises much discussion pertaining to her plight, especially when keeping in mind the complexities associated with the issues of migration (Michael 2011:392-410). For example, Ruth becomes nothing more than a handmaid for Naomi and disappears from the narrative when Obed is born (Michael 2011). In an attempt to empathise with Ruth's plight, Long (2014) posits:

Ruth contains many elements that make for good story-tragedy, conflict, romance, and redemption to name a few. This gripping story causes 'the emotions of the reader to fluctuate between hope and despair until the very end when what began with multiple tragedies comes to a triumphant and happy conclusion'. (p. 14)

Apparently, an understanding of the consequences associated with Ruth's decision to migrate with Naomi to Judah is important in complex migration situations. It is unfortunate that, owing to space constraints, the issues cannot be discussed in this article.

The story of Boaz and Ruth is reminiscent of the practical pattern of how the Israelites positively deal with the migrants amongst them (i.e. the story of Ruth and Boaz shows the application of the latter part of Deuteronomy 24:19-22, as Merrill [1994:324] notes). ${ }^{4}$ It can be perceived that the migration of Elimelech and his family to Moab is in God's plan. From a redemptive perspective, although Elimelech and his family migrate to Moab because of famine in the land of Judah, one can also argue that God, in his grace and divine providence, might have used their going to Moab to reach people such as Ruth (from a Gentile ethnic group) so that they can be saved. When Naomi is about to return to Judah, after hearing that God had 'visited her people' by providing them with food, Ruth (Rt 1:16-18) confesses her faith in the God of Israel, thus confirming that she is already converted (Branch 2012:1). At this point, it does not matter whether Ruth confesses her faith to the God of Israel because she is afraid of being alone when Naomi returns to Judah or it is because of her own personal faith (Rt 1:16-18). Instead, what matters is that Ruth 'switches allegiance from the gods of Moab to the God of Israel' (Branch 2012:1). It can be argued, therefore, that when Elimelech and his family migrate to Moab, they become God's instruments of salvation to many Moabites by word and deeds. Ruth could have been converted when she married Elimelech's son. Naomi's words to her daughters-in-law suggest that if they leave her, they would be going back to their people and their gods. Thus, when Ruth affirms that the covenant people of God (the people of Naomi) will be her people and the covenant God of Israel (the God of Naomi) will be her God (Rt 1:16-18), it is apparent at this point that Ruth has expressed her faith in the God of Israel, whom she acknowledges and believes in by virtue of her contact with Elimelech and his family.

The interconnection between the migration of Elimelech and his family and Ruth's expression of her faith can be taken to

4.In Deuteronomy $24: 19-22$, the landowners in Israel were commanded by God to leave some crops in the fields for the aliens to glean. 
imply that God uses migration in the fulfilment of his redemptive purposes and plans for humankind. It also connotes the underlying truth that the people/nations that God intends to reach through Israel, individually and collectively, are evangelised and converted when God, in his grace and sovereignty, migrates his people to the unreached. Consequently, the hitherto unreached people/nations are saved by virtue of encountering the people of God. However, the above is mentioned in cognisance of the fact that it is not necessarily by God's command that his people migrate. Some are forced to migrate because circumstances leave them no choice, as is the case with Elimelech and his family. However, this is not to say that God cannot use such circumstances.

Ruth 1:19 confronts the reader with the migration of Naomi and Ruth to Judah at the end of the famine in Judah. This migration is crucial in the sense that it shows the marriage of Ruth to Boaz, as well as the application of the law of Deuteronomy by Boaz. However, without going into detailed discussion regarding Boaz's application of Deuteronomy 24:19-22,5 it can be advanced that God uses Boaz and Ruth's marriage (Rt 4) to advance his redemptive purposes and plans for Adam and his descendants. This demonstrates that, in his grace and divine providence, God migrates Ruth and Naomi to Judah (Rt 1:19ff.) and then allows Boaz to marry Ruth, who conceives and gives birth to Obed, the father of Jesse, who is the father of David (Rt 4:17). David becomes the king of Israel and enters into an eternal covenant with God about David's throne, which God declares will endure forever (2 Sm 7ff.). The genealogy in Matthew 1 also amplifies David's genealogy in Ruth 4:18-22 by making a significant link between Jesus Christ (the Saviour of all people) and David, as it denotes Jesus as a Davidic son (Mt 1:1-25).

Given this, it is in Matthew's rendering that one perceives the inclusion of Ruth in Jesus' genealogy. In saying this, the narrative moves towards the establishment that this Gentile woman, Ruth, as well as Tamar and Rahab, come to be in Jesus' genealogy in order to demonstrate the crucial roles they played, together with many others, in ways that illustrate the role and place of migration in God's redemptive plans. With this in mind, this paper accordingly contends that the individual and corporate factors for migration should be understood from God's perspective, i.e. as God's providence in migrating his people in order to work out his redemption plans for humankind.

5.In Deuteronomy 24:19-22, God commands the landowners in Israel to leave some crops in the field so that the aliens can come and glean (Merrill 1994:324). In the context of Ruth and Boaz's narrative, it is apparent that Boaz is considered one of the Israelite landowners who apply the law of the proposed passage in Deuteronomy. As Atkinson (1983:60) notes, the theology of this practice is underlined by the fact As Atkinson (1983:60) notes, the theology of this practice is underlined by the fact that the covenant pecause God is God who rescues slaves and cares for the poor, helpless and needy, so the sociothe people la the per is nature. The implicit belief is that the land ultimately belongs to God, and that his concern for the poor and the underprivileged finds economic expression in thes ways (Atkinson 1983:60)

\section{A study of God's use of migration to accomplish his redemptive purposes and plans for humankind: A perspective from Matthew's genealogy}

Emerging from the above biblical theological analysis of migration in the OT is a firm conviction that Tamar, Rahab and Ruth, the key women in Jesus' genealogy, have been recognised by all as coming from the so-called Gentile ethnic groups (cf. Heffern 1912:69-81; Lee 2007:49-74). In our view, these women are incorporated into Jesus' lineage in order to accomplish the unfolding of God's redemptive plan for humankind. However, it is important to note that scholars (i.e. Botha 2006; Garland 1979; Heffern 1912; Heil 1991:538545; Hill 1972; Hutchison 2001; Lee 2007; Morris 1992; Nolan 1979; Nowell 2008) do not discuss the fact that these Gentile women - Tamar, Rahab and Ruth - become part of Jesus' genealogy because of the narratives of migration in redemptive history. At this juncture, this author is aware that the readers may wonder what evidence the Gospel of Matthew presents with regard to migration. In responding to the presupposed question, this paper argues that the mention of Tamar, Rahab and Ruth in Matthew's genealogy (as explained in Sections 3.1, 3.2. and 3.3) is an indication that migration is an important aspect of redemptive history; hence, it is worthy of rigorous scholarly scrutiny.

However, many scholars attempt to investigate the significance of these women in Jesus' genealogy ${ }^{6}$ in view of the intention and purpose of Matthew (cf. Heffern 1912:69; Lee 2007:49). For example, Lee (2007) argues that the significance of the inclusion of Tamar (Mt 1:3), Rahab (Mt 1:5), Ruth (Mt 1:5), Bathsheba, the wife of Uriah (Mt 1:6) and Mary (Mt 1:16) should be examined in light of Matthew's intention and purpose as a whole. In Lee's (2007) view, it is unusual for Jewish genealogy to include women, except 'in cases such as an irregularity of pedigree or some notable connection' (Lee 2007:49, cf. Nolan 1979:62). The inclusion of these women in Jesus' genealogy is surprising because, although they are a significant part of the history of the Israelites, 'they are not the more prominent matriarchs of Israel such as Sarah, Rebecca, Rachel, and Leah' (Lee 2007:49). In Lee's (2007:49-50) opinion, there is a school of thought that Tamar, Rahab, Ruth and Bathsheba are 'disreputable sinners in relation to sexual sins'. For example, Tamar pretends to be a prostitute so that Judah would lie with her, Rahab is a prostitute, Ruth seduces Boaz (Rt 3:1-18) and Bathsheba commits the sin of adultery with David.

Given the nature of the women mentioned by Lee (2007) above, Morris (1992:23) advances that the purpose of their inclusion in Jesus' genealogy is to emphasise the fact that Jesus was the Saviour of sinners. In saying this, Morris (1992) also perceives the Gentile backgrounds of the four women as appropriate evidence to suggest the centrality of Matthew's message as 6.Luke only mentions Mary in his genealogy of Jesus. 
emphasising mission to the Gentiles. In amplifying the various understandings of the purpose of the inclusion of these four women of Gentile ethnic origin in Matthew's genealogy of Jesus, Heffern (1912:70) argues that some scholars perceive the mention of Ruth as depicting the interest of Matthew in advancing the inclusion of the 'Gentiles in the Church of the Messiah', who is also a true descendant of the Gentiles.

However, it can be posited that Morris' (1992) conception that the inclusion of women in Jesus' genealogy serves to emphasise that Jesus was incarnated for sinners, leaves out some important aspects of the message, for example, those pertaining to God's use of migration in accomplishing his redemptive purposes for humankind. Morris' (1992) view can be challenged since the NT presents Rahab as an example par excellence of faith (Heb 11:31) and good works (Ja 2:25) (Lee 2007:50). Furthermore, this article concurs with Lee (2007:50) and Garland (1979:18) that Morris' (1992) conception of the purpose of the inclusion of these Gentile women in Jesus' genealogy is problematic because it ignores the wellknown sinfulness of many men in this genealogy, such as Manasseh (Mt 1:10), who is qualified in 2 Kings 21:1-18 as the most evil king of Israel. Given the aforementioned reasons, the view that these women were included in the genealogy to emphasise that Jesus was incarnated for sinners ignores important aspects that have to be included to achieve a fuller and more balanced position on the matter.

Nevertheless, in diverging from Morris' (1992) view, Hill (1972:74) and Heil (1991:538-545) affirm that these women are mentioned in Matthew's genealogy because they play a distinct role in the unfolding of God's mission to humankind at different stages of God's redemptive history for humanity. As has been repeatedly argued, the above women keep the leading lineage of Israel alive. It is this lineage that brings into being Jesus Christ, the Saviour of the world. ${ }^{7}$ In the same vein, Lee (2007:61) attempts to understand the purpose of the inclusion of these four Gentile women in the genealogy of Jesus by locating them in the wider context of the book of Matthew. In Lee's (2007) view, Matthew's purpose is to establish that both Jews and Gentiles are in fellowship with God through the Messiah, Jesus Christ. In other words, Matthew's emphasis lies in the universal salvation, which is achieved for both Jews and Gentiles through Christ (Lee 2007). In summarising his view of the inclusion of these Gentile women in Jesus' genealogy, in view of the purpose of Matthew's gospel, Lee (2007:67-68, cf. Hutchison 2001:152ff.) gives a prolonged assertion that the reasons for Matthew's:

\footnotetext{
... inclusion of four Gentile women in the genealogy are, therefore, not incidental but rather intentional for charting the new direction of his community to an inclusive mission. In particular, two main facts support this. First, women are not usually included in Jewish genealogy. Second, they are not like the great women to be found in Jewish writings such as Sarah, Rebecca, Rachel, and Leah. Matthew's theological direction, therefore, is through the transforming community, toward an inclusive mission which is clearly distinguishable from Judaism. (p. 67-68)
}

7.For more views on the inclusion of these four Gentile women in the genealogy of Jesus Christ, see Lee (2007:49-74).
At this point, this article both agrees and disagrees with Lee (2007). One can concur with Lee (2007) on the fact that Matthew shows the universal salvation that is achieved for both Jews and Gentiles through the Messiah, Jesus Christ. However, the point of departure emanates from Lee's (2007) affirmation that the inclusion of these women of Gentile ethnic origin demonstrates the nature of the new community inaugurated by the universal Saviour, Jesus Christ. Lee's (2007) conception of the purpose of the inclusion of the four Gentile women by Matthew is problematic: it does not seem to take into account that in the OT, Abraham and his descendants are given a role in the unfolding of God's redemption for all humankind ( $\mathrm{Gn}$ 12:3). The role Abraham and his descendants play is to bring salvation to Gentile nations, as seen in the conversion of Gentiles in the context of the migration of God's people in redemptive history. God employs both Rahab and Ruth in the unfolding of his redemptive plan for humankind, as Jesus' genealogy in Matthew 1:3-5 attests (Hill 1972:74). Therefore Hutchison (2001:152-153) argues that God uses these faithful Gentile women in preserving the Messianic line of Abraham and David, which culminates in Jesus Christ, as the Saviour of all nations, ${ }^{8}$ as Matthew 1:21 attests.

In other words, Lee's (2007) approach seems to suggest a discontinuity between the Old and New Testaments' views of redemption, yet Matthew's genealogy attests to that continuation. On one hand, Lee (2007) seems to picture the OT as affirming redemption in a way that excludes Gentiles. On the other hand, the NT is pictured as doing a new thing of welcoming Gentiles into fellowship with God, based on their faith in the Messiah, Jesus Christ (cf. Heffern 1912:81). Indeed, this paper differs with Lee (2007), since there is arguably continuity in the unfolding of God's redemptive history between the Old and New Testaments. Viljoen (2011:2, cf. Schweizer 1975:21-26) examines Matthew's genealogy and argues that Matthew 1:1 starts by designating the title 'Son of David and Son of Abraham' so as to explain that Jesus Christ (the one who fulfils Israel's role of bringing salvation to the nations in Mt 1:21) is rooted 'in Israel's messianic expectations, history and Scriptures'. Torrance (1992:3, cf. Kruger 2007:1) concurs when he argues that conferring titles such as Son of David and Abraham on Christ in Matthew's genealogy indicates Jesus Christ's 'intimate bond with Israel in its covenant relationship with God throughout history'.

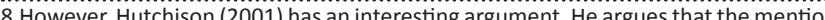
of these four OT women of Gentile ethnic origin alludes to common stories that demonstrate the same point. Having said that, he advances these points to the 'OT periods of the patriarchs, the conquest, the judges, and David's kingdom, and, in each case, a Gentile shows extraordinary faith, in contrast to Jews, who are greatly lacking in their faith. The faith of Tamar versus that of Judah, of Rahab versus that of the Israelites in the wilderness, and of Ruth versus that of the judges' generation illustrate that, at crucial times in Israel's history, Gentiles demonstrated more faith than Jews in response to God. Bathsheba is probably cited by Matthew as the wife of Uriah in order to focus attention on Uriah's faith in contrast to that of David. Through all of this, God remains faithful in preserving the messianic line, and in Through all of this, God remains faith ul in preserving the messianic line, and in some cases he does it through godly Gentiles. These contrasts are consistent with Matthew's purpose to remind Jews of God's faithfulness to his Abrahamic and Davidic covenant promises: to lead them to a more accurate understanding of the messianic kingdom, and to exhort them to forsake the self-righteous attitude of many Jews toward Gentiles, who are now joining them in the church. Matthew accomplishes this by reminding them of the crucial role the Gentiles play in the messianic story'. 
Furthermore, from a systematic conception of the Old and New Testaments, Horton (2011:19-107), Torrance (2008:44), Wright (1991:36), Magezi and Magezi (2017:155-158) and Kruger (2007:2) all agree with this when they advance Christ as the one who fulfils the OT covenant promises that God designed to achieve through Abraham and his descendants (the Israelites), as his covenant people. For instance, Torrance (2008:45) views Christ as the centre of redemptive history, since the OT looks forward to the fulfilment of the redemptive promises in and through Christ, whilst the NT looks back to the promises of the redemptive history that culminates in Christ. One can encapsulate this concept by affirming Torrance's (2008) ensuing words:

$[T]$ he center of gravity is in the incarnation itself, to which the OT is stretched out in expectation, and the NT looks back in engulfment. This one movement throughout the OT and NT is the movement of God's grace in which he renews the bond between himself to man in such a way as to assume human nature and existence into oneness with himself. (p. 45)

Stated differently, the continuity between the two Testaments is that God's redemptive promise for humankind (that he commits himself to accomplish through Abraham and his descendants in Genesis 12:3 and has now found its climax in Jesus Christ) has always been about the salvation of people from Gentile ethnic groups (Torrance 2008:40-45). That is, God's salvific story, particularised in Israel in the OT and fulfilled by Jesus Christ in the NT, is designed by God to extend to all people through faith in Jesus Christ (Magezi \& Magezi 2017:158). Having established the continuity between the Old and New Testaments, this paper unswervingly upholds that many OT narratives, such as that of Ruth and Rahab (that find their fulfilment in Jesus Christ) attest to the enduring nature of God's salvific purpose for humankind in the context of migration in redemptive history.

At this juncture, we need to take note of the fact that God does not solely advance his redemptive plans and purposes for humankind through the migrations that he commands his people to undertake - such as his command for Israel to conquer Canaan (Dt 2), their obedience (Jos 6:21) and the culmination in Rahab's conversion (Jos 6:22-23). Instead, God also utilises migrations that are caused by circumstances that leave people with no choice but to migrate (as is the case of Elimelech and his family, in the wider context of Rt 1:1-18) and unleash his redemption purposes and plans to the world. This way, one contends that all the individual and corporate factors for migration such as famine, persecution and many others may, in this case, also receive a more than human aspect in God's providential control of everything that has to do with human beings, as he works out his plan to fulfil his promises (Magezi 2019:6; Medeiros 2013:174). That is to say, migration does not happen by chance; instead, it is sovereignly planned and executed by God as perceived in the salvation and inclusion of some women of Gentile ethnic origin in the leading line of Israel in the OT (Magezi 2019:6; Medeiros 2013:174). These women are included in Matthew's genealogy as they play an important role in advancing the genealogy of Jesus, who is the saviour of the world.
Emerging from the aforesaid theological conception is the notion that the migrants that approach the doorsteps of Christians are not there by accident. Instead, God is using their various migrations, some that might be associated with sorrow and pain, to advance his plans and purposes for the world. This theological notion has huge implications on the contemporary context of migration, in which the Church is not participating effectively (Groody 2009:640; Heimburger 2015:338). It can be posited that the contemporary Church is not effectively responding to migration challenges because it lacks biblical-theological foundational statuses of migration theology (Magezi \& Magezi 2018:320-321). The proposed understanding, thus, challenges the Church to respond to migrants' challenges in an effective manner, as well as challenging theology to claim its space in the discourse of migration, because God is in the shadow of these various migrations, which he uses to accomplish his purposes and plans for humankind (Medeiros 2013:174). Unfortunately, as Magezi (2019:7) notes, humanity does not know the exact migrants that God is utilising to unleash his plans and purposes for the world, thus, the duty of the Church is to simply embrace all migrants and respond to their challenges, as God works out his plans and purposes through them (migrants).

\section{Conclusion}

In conclusion, this article responds to the emerging need for theology to engage more with the issues surrounding migration, and to develop a thorough biblical-theological foundation for migration theology that challenges churches to devise effective responses to migrants' challenges. The paper ventured into a study of God's use of migration to accomplish his redemptive purposes and plans for humankind, as reflected in Matthew's genealogy. Although there are many patriarchs of Israel (e.g. Abraham, Isaac, Jacob) in Matthew's genealogy who are involved in the various migrations that God uses to advance his redemption plans, this article argued that the salvation and inclusion of women from Gentile ethnic groups (i.e. Tamar, Rahab and Ruth) in Jesus' genealogy emphasises the importance of migration in redemptive history.

At this juncture, the emerging view of migration in redemptive history is that the salvation and inclusion of the Gentile women Tamar, Rahab and Ruth in Jesus' genealogy, as rendered in Matthew, is crucial in challenging Christians to understand that, in God's scheme, migration is not an accident. Instead, it is an instrument that God uses to accomplish his redemptive plans and purposes for humanity. This theological aspect of migration in redemptive history, which emerges from Matthew's genealogy, challenges humankind to respond positively to migrants. It also challenges theology to engage more in migration issues, because migrants are brought to some people's doorsteps by God, for purposes that are unknown to them. Given this, the individual and corporate factors for migration (such as famine and persecution), that are associated with pain and tears, should not be viewed solely from a human perspective. Instead, migration should also be perceived as God's 
providential control of everything that has to do with human beings, as he works out his plan to fulfil his promises.

\section{Acknowledgements}

This article is part of a PhD study on migration that was done at North-West University, Vaal Triangle Campus.

\section{Competing interests}

The author has declared that no competing interest exists.

\section{Author's contributions}

This is a sole authored article. The author contributed in researching, analyses and writing of the article.

\section{Ethical considerations}

This article followed all ethical standards for research without direct contact with human or animal subjects.

\section{Funding information}

This research received no specific grant from any funding agency in the public, commercial or not-forprofit sectors.

\section{Data availability statement}

Data sharing is not applicable to this article as no new data were created or analysed in this study.

\section{Disclaimer}

The views and opinions expressed in this article are those of the author and do not necessarily reflect the official policy or position of any affiliated agency of the author.

\section{References}

Arnold, B.T., 2009, Genesis: The new Cambridge Bible commentary, Cambridge Press, Cambridge.

Athas, G., 2016, Deuteronomy: One nation under God, Aquila Press, Sydney.

Atkinson, D., 1983, The message of Ruth, Inter-Varsity Press, Nottingham.

Bose, S., 2014, 'Illegal migration in the Indian Sunderbans', Forced Migration Review 1(45), 22, viewed 30 March 2016, from http://connection.ebscohost.com/c/ articles/94903338/illegal-migration-indian-sunderbans.

Botha, P.J., 2006, 'Tamar, Rahab, Ruth, and Mary - The bold women in Ephrem the Syrian's Hymn De Nativitae 9', Acta Patristica et Byzantina 17(1), 1-21. https:// doi.org/10.1080/10226486.2006.11745765

Boundless, 2015, 'Impact of immigration on the host and home country economies', Boundless Economics, viewed 18 May 2016, from http://oer2go.org/mods/enboundless/www.boundless.com/economics/textbooks/boundless-economicstextbook/immigration-economics-38/introduction-to-immigration-economics-138/ impact-of-immigration-on-the-host-and-home-country-economies-546-12643/ index.html.

Branch, R.G., 2012, 'Handling a crisis via a combination of human initiative and godly direction: Insights from the Book of Ruth', In die Skriflig/In Luce Verbi 46(2), Art \#110, 11 pages. https://doi.org/10.4102/ids.v46i2.110

Campese, G., 2012, 'The irruption of migrants: Theology of migration in the 21st century', Theological Studies, 73(1), 3-32. https://doi.org/10.1177/004056391207300101

Chelius, L.C., 2014, Mexicans seeking political asylum, viewed 28 May 2016, from http://www.fmreview.org/crisis/calderon.html.

Corhen, J.H. \& Sirkerci, I., 2011, Cultures of migration: The global nature of contemporary mobility, University of Texas Press, Austin, TX.
Datta, K., Mcllwaine, C., Evans, Y., Herbert, J., May, J. \& Wills, J., 2006, Work and survival strategies among low-paid migrants in London, Department of Geography, Queen Mary, University of London, London, viewed 20 May 2016, Geography, Queen Mary, University of London, London, viewe
from http://www.geog.qmul.ac.uk/globalcities/wpaper3.pdf.

Ford, W., 2017, 'The challenge of the Canaanites', Tyndale Bulletin 68(2), 161-184.

Garland, D.E., 1979, The intention of Matthew 23, Brill, Leiden. https://doi. org/10.1163/9789004266636

Geisler, N.L., 1977, A popular survey of the Old Testament, Baker, Grand Rapids, MI.

Gilmore, K., 2016, Keynote address: Side event 'Migrants in transit', viewed 20 May 2016, from https://www.ohchr.org/EN/NewsEvents/Pages/DisplayNews.aspx?NewsID= 18485\&LangID=E.

Gopal, N., 2013, “'They call us Makwerekweres" - Foreign learners speak out against xenophobia', Alternation (7), 125-144. http://alternation.ukzn.ac.za/Files/docs/ 20.4/Alternation $\% 2020.4 \% 20$ (2013).pdf

Grisanti, M.A., 1998, 'Israel's mission to the nations in Isiah 40-55: An update', TMS 9(1), 39-61.

Groody, D.G., 2009, 'Crossing the divide: Foundations of a theology of migration and refugees', Theological Studies 70(3), 638-667. https://doi.org/10.1177/0040563 90907000306

Harris, B., 2002, 'Xenophobia: A new pathology for a New South Africa', in D. Hook \& G. Eagle (eds.), Psychopathology and social prejudice, pp. 169-184, University of Cape Town Press, Cape Town.

Heffern, A.D., 1912, 'The four women in St. Matthew's genealogy of Christ', Journal of Biblical Literature 31(2), 69-81. https://doi.org/10.2307/3259170

Heil, J.P., 1991, 'The narrative role of the women in Matthew's genealogy', Biblica 72(4), 538-554.

Heimburger, R.W., 2015, 'Fear and faith in the kin-dom: New explorations in the theology of migration', Modern Theology 31(2), 338-344. https://doi.org/ $10.1111 /$ moth.12150

Hill, D., 1972, 'The Gospel of Matthew', NCB, Marshall, Morgan and Scott, London.

Horton, M., 2011, Christian faith: A systematic theology for pilgrims in the way, Zondervan, Grand Rapids, MI.

Hutchison, J.C., 2001, 'Women, Gentiles and the Messianic mission in Matthew's genealogy', Bibliotheca Sacra 158(630), 152-164.

Jackson, D. \& Passarelli, A., 2016, Mapping migration: Mapping churches' responses in Europe, viewed 23 May 2016, from http://www.ceceurope.org/wp-content/ uploads/2015/07/2016-01-08-Mapping_Migration_2015_Online_lo-res_2_.pdf.

Japhet, S., 2006, From the rivers of Babylon to the highlands of Judah: Collected studies on Restoration period, Eisenbrauns, University Park, PA.

Kruger, B., 2007, On the road to becoming flesh: Israel as the womb of the incarnation in the theology of T. F. Torrance, viewed 20 June 2020, from http://www.tftorrance. org/journal/v3/participatio-2012-v3-2-Kruger-64-91.pdf.

Kul, Y., 2011, Opportunities and challenges of international migration for sending and receiving countries, viewed 04 June 2016, from http://www.mfa.gov.tr/ opportunuties-and-challenges-of-international-migration-for-sending-andreceiving-countries.tr.mfa.

Lee, S., 2007, 'Matthew's concern for mission by including the four women (Matthew 1:1-17)', Torch Trinity Journal, 10(1), 49-74.

Long, S.C., 2014, 'The Book of Ruth as an exemplar for faith communities', Priscilla Papers 28(4), 14-17.

Louw, D.J., 2016, 'Between xenophobia and xenodochia in an operative ecclesiology of home: The plight of refugees and migrants as challenge to a diagnostic approach in a pastoral hermeneutics of caregiving', unpublished paper.

Magezi, C., 2017, 'Migration crisis and the church: A response to lacunae and considerations for Christian ministry engagement', Verbum et Ecclesia 38(1), a1671. https://doi.org/10.4102/ve.v38i1.1671.

Magezi, C., 2018, 'Theological understandings of migration and church ministry model: A quest for holistic ministry to migrants in South Africa', PhD thesis, North West University, Potchefstroom.

Magezi, C., 2019, 'Migration history in South Africa as a lens for interpreting God's mission: Towards a challenge for churches to embrace migrants', Verbum et Ecclesia 40(1), a1887. https://doi.org/10.4102/ve.v40i1.1887

Magezi, V. \& Magezi, C., 2017, 'An Adamic incarnational Christological framework as a theological approach for African contextual ministry', Missionalia 44(2), 152-174. https://doi.org/10.7832/44-2-111

Magezi, V. \& Magezi, C., 2018, 'Migration crisis and Christian response: From Daniel De Groody's image of God theological prism in migration theology to a migration practical theology ministerial approach and operative ecclesiology', HTS practical theology ministerial approach and operative ecclesiology, HTS
Teologiese Studies/Theological Studies 74(1), 4876. https://doi.org/10.4102/hts. Teologiese Stud
v74i1.4876

Medeiros, E., 2013, 'God scatters to gather through his people. A missional response to migrant churches', in S.T. Logan (ed.), Reformed means missional, pp. 173-188, to migrant churches', in S.T. Logan (ed.),

Michael, M., 2011, 'Orpah and her interpreters: Evaluating the justifications for the traditional-stereotyped readings', OTE 24(2), 390-413.

Merrill, E.H., 1994, Deuteronomy: An exegetical and theological exposition of Holy Scripture, Broadman \& Holman, Nashville, TN.

Morris, L., 1992, The gospel according to Matthew, Eerdmans, Grand Rapids, MI.

Motyer, J.A., 1986, The message of Genesis 12-50: From Abraham to Joseph, InterVarsity Press, Leicester. 
Nie, Z., 2015, 'The effects on host countries', globalEdge Blog, viewed 23 May 2016, from https://globaledge.msu.edu/blog/post/30996/the-effects-of-refugees-on-host-

Nolan, B.M., 1979, The Royal Son of God: The Christology of Mt 1-2 in the Setting of the Gospel, Vandenhoeck \& Ruprecht, Göttingen.

Nowell, I., 2008, 'Jesus' great grandmothers: Mathew's four and more', The Catholic Biblical Quarterly 70(1), 1-15.

Pakoz, Z., 2016, 'Refugee haven under attack', Mail \& Guardian, 20-26 May.

Plucinska, J., 2015, 'The Paris attack have put Europe's refugee crisis under renewed scrutiny', TIME 16 November, viewed 27 May 2016, from time.com/4114009/ paris-attacks-migrant-crisis-refugees-eu/.

Rajendra, T.M., 2014, 'Justice and benevolence: Catholic social thought, migration theory, and the rights of migrants', Political Theology 15(4), 290-306. https://doi. org/10.1179/1462317X13Z.0000000007

Ridsdel, J., 2014, 'Adolescence, food crisis and migration', Forced Migration Review 45, $27-$ 28, viewed 02 April 2016, from https://www.files.ethz.ch/isn/176966/ crisisNo45.pdf.

Rivera-Pagán, L.N., 2012, 'Xenophilia or xenophobia: Towards a theology of migration', The Ecumenical Review 64(4), 575-589. https://doi.org/10.1111/erev.12013

Rosenblum, W.I., 2002, 'Tamar three times', Jewish Bible Quarterly 30(2), 127-130, viewed 16 April 2018, from jbqnew.jewishbible.org/assets/Uploads/302/302_TAMAR2.

Sazonov, A., 2015, 'Paris attack and Europe's response to the refugee crisis', HuffPost, 02 December, viewed 17 April 2016, from http://www.huffingtonpost.com/ european.../paris-attacks-and-europes_b_8684636.html.
Schweizer, E., 1975, The good news according to Matthew, John Knox Press, Westminster.

Skeldon, R., 2013, 'Global migration: Demographic aspects and its relevance for development', Technical Paper no. 2013/6, United Nations Department of Economic and Social Affairs, viewed 27 March 2016, from https://www.un.org/ en/development/desa/population/migration/publications/technicalpapers/ en/development/desa/population/n.

Tan, J.Y. 2012, 'Migration in Asia and its missiological implications: Insights from the migration theology of the Federation of Asian Bishops' Conference (FABC)', Mission Studies 29(1), 45-61. https://doi.org/10.1163/157338312X638019

Thomsen, P.M., 2016, The refugee surge in Europe: Economic challenges, viewed 28 May 2016, from https://www.imf.org/external/pubs/ft/sdn/2016/sdn1602.pdf.

Torrance, T.F., 1992, The mediation of Christ, Eerdmans, Grand Rapids, MI.

Torrance, T.F., 2008, Incarnation: The person and life of Christ, IVP Academic Press, Downers Grove, IL.

Ulrich, D.R., 2007, From famine to fullness: The gospel according to Ruth, P\&R Publishing, Phillipsburg, NJ.

Viljoen, F.P., 2011, Matthews's portraits of Jesus: Six studies in Matthew Potchefstroomse Teologiese Publikasies, Potchefstroom

Wright, N.T., 1991, The climax of the covenant: Christ and the law in Pauline theology, T\&T Clark, Edinburgh. 